\title{
AN ENGLISH FAMILY WITH WAARDENBURG'S SYNDROME
}

\author{
BY \\ M. W. PARTINGTON* \\ From the Jenny Lind Children's Hospital, Norwich
}

(RECEIVED FOR PUBLICATION OCTOBER 8, 1958)

In 1951 Waardenburg first described a syndrome consisting of (1) lateral displacement of the inner canthi of the eye and of the inferior lacrimal punctae (dystopia canthorum), (2) a high broad nasal root, (3) confluence of the eyebrows with hypertrichosis of their medial parts, (4) partial or total heterochromia iridum, (5) a white forelock, and (6) unilateral or bilateral congenital deafness. From his extensive material Waardenburg concluded that the syndrome has a dominant autosomal inheritance but that each of its components shows a variable penetrance. Thus out of his 161 affected individuals from 14 families, 99\% had dystopia canthorum, $78 \%$ the broad nasal root, $45 \%$ the confluent eyebrows, $25 \%$ heterochromia iridum, $20 \%$ congenital deafness and $17 \%$ a white forelock. He estimated that in the Netherlands this syndrome accounts for about $1.43 \%$ of all deaf mutes, and that in whole or in part it occurs in 1 in 42,000 persons.

Except for one Swiss subject all Waardenburg's cases were Dutch. From the literature he recognized two probable American cases and possible German and Italian examples. Keizer (1952) described another Dutch family and Wildervanck (1957) reported a further five cases also from Holland. Mackenzie (1958) has described an example from Scotland. On the other hand, Klenka (1956) examined 374 deaf mutes in Prague and was unable to find a single typical case. No other examples have been found in the literature. It seemed, therefore, that the present pedigree was worth recording.

\section{Family History}

The Family. The family pedigree is shown in Fig. 1. The propositus was brought to hospital because of obvious congenital deafness. Her parents (IV-1 and 2, see pedigree) provided much of the family history. The maternal grandfather (III-5) and his second wife (not shown in the pedigree) were also interviewed and several

* Present address: Department of Child Health, University of Sheffield. photographs were available. The white forelock is well recognized by them as an inherited feature. The family all live in Norfolk and have done so for many generations.

I-2. This lady probably showed part of the syndrome but the evidence is meagre. She is remembered as having had a similar appearance around the eyes and nose to other affected persons in the family but a good full-face photograph shows only thick eyebrows and a high, wide nasal root.

II-4. The grandmother was clearly affected. She had a small white forelock, one iris was blue and the other brown. As judged from three photographs she had dystopia canthorum and a broad nasal root. She died, probably from pneumonia, in her early forties.

II-6. A sister of the above had no white forelock but from a good photograph she seems to have had dystopia canthorum and the typical nasal root. She never married and died at the age of 50 from cancer (site unknown).

III-6. The only daughter of II-4 had a white forelock as a child and as a young woman, but did her best to hide it. At the age of about 23 years her hair went completely grey. Her eyebrows tended to grow together in the midline but her eyes were both the same blue colour. She is also remembered as having had the characteristic appearance of the eyes and nose but this is not obvious from the one available photograph. She died at the age of $\mathbf{4 0}$ from hypertension.

IV-2 (Fig. 2). The mother of the propositus has a broad white forelock (which as a child her mother had tried to hide). She has dystopia canthorum with lateral displacement of the inferior lacrimal punctae so that they lie opposite the inner edge of the cornea. The distance between the inner canthi is $\mathbf{4 0} \mathrm{mm}$., the interpupillary distance is $60 \mathrm{~mm}$., and the outer canthal distance is $100 \mathrm{~mm}$. The irises are blue with a hazel tinge and are of the same colour. The nose root is broad and the eyebrows tend to grow together in the midline. (This latter trait is not seen in Fig. 2 because the eyebrows are plucked). At the age of 6 years she had measles and after this was found to be deaf in the right ear. She was 


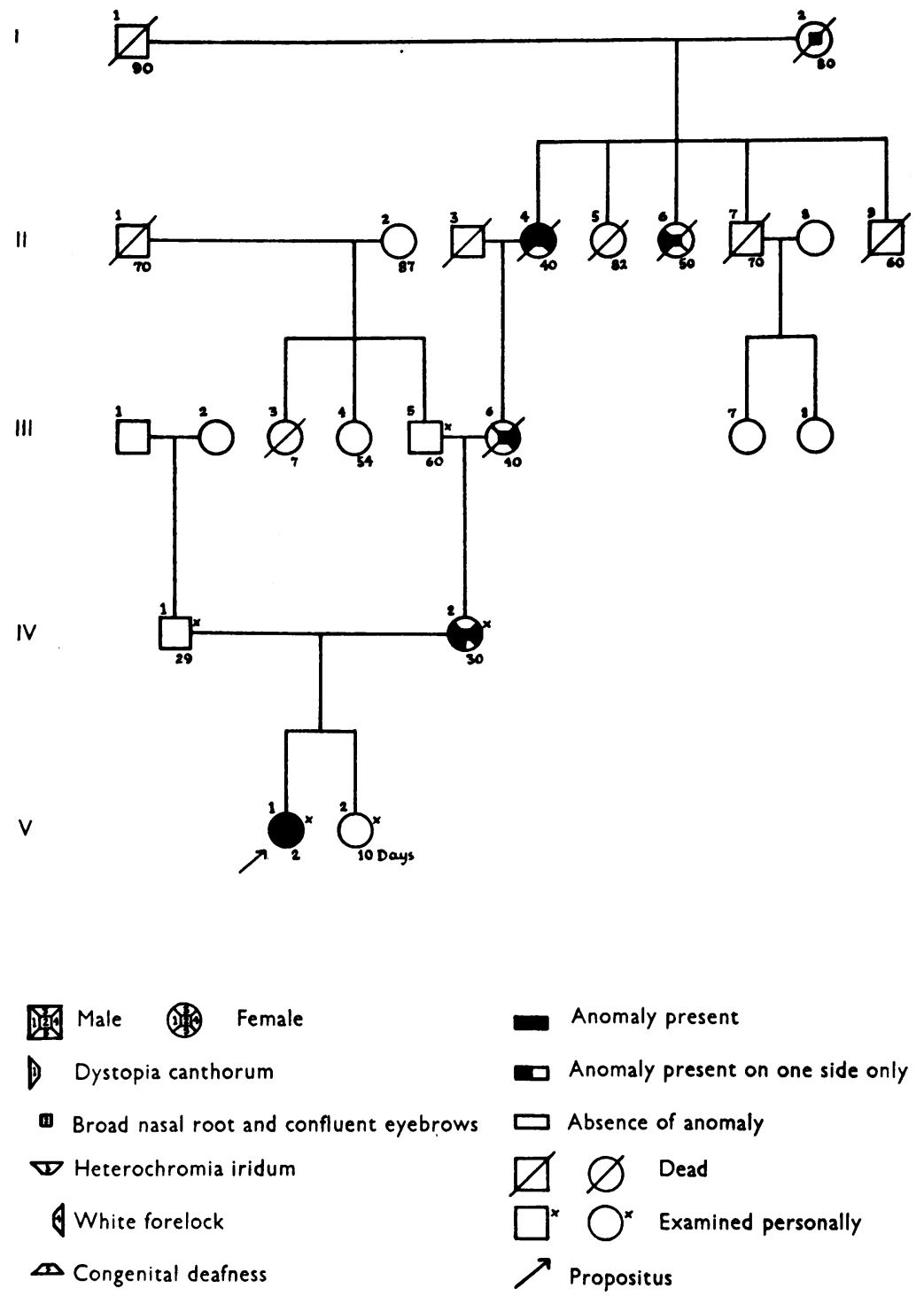

FIG. 1.-The pedigree (Waardenburg's symbols).

seen by an aural specialist who said that the "nerve had been destroyed '. She is completely deaf on that side. She has a patch of albino hairs about $3 \mathrm{~cm}$. across on the left leg. She is in good health.

V-1. The propositus is now aged 2 years. She was born at full term after a normal pregnancy. The white forelock was noticed at birth. The inner quarters of the eyebrows and the inner halves of the eyelashes are also white. The nasal root is broad and the eyebrows grow together in the midline (this is not obvious in Fig. 2 because the hairs are white). The eyes are intensely blue but at 10 o'clock in the right iris there is a light brown patch about $3 \mathrm{~mm}$. across. There is dystopia canthorum and the inferior lacrimal punctae lie opposite the inner edge of the cornea. The inner canthal distance is $32 \mathrm{~mm}$., the interpupillary distance $55 \mathrm{~mm}$., and the outer canthal distance $90 \mathrm{~mm}$. She appears to be totally deaf, only responding to loud vibratory noises. She babbles and mouths words. She is not retarded except in speech. There is an irregular patch of skin on the inner arm which fails to pigment in sunlight and a similar streak runs down the middle of her forehead. She has had no major illnesses and is in good general health. 


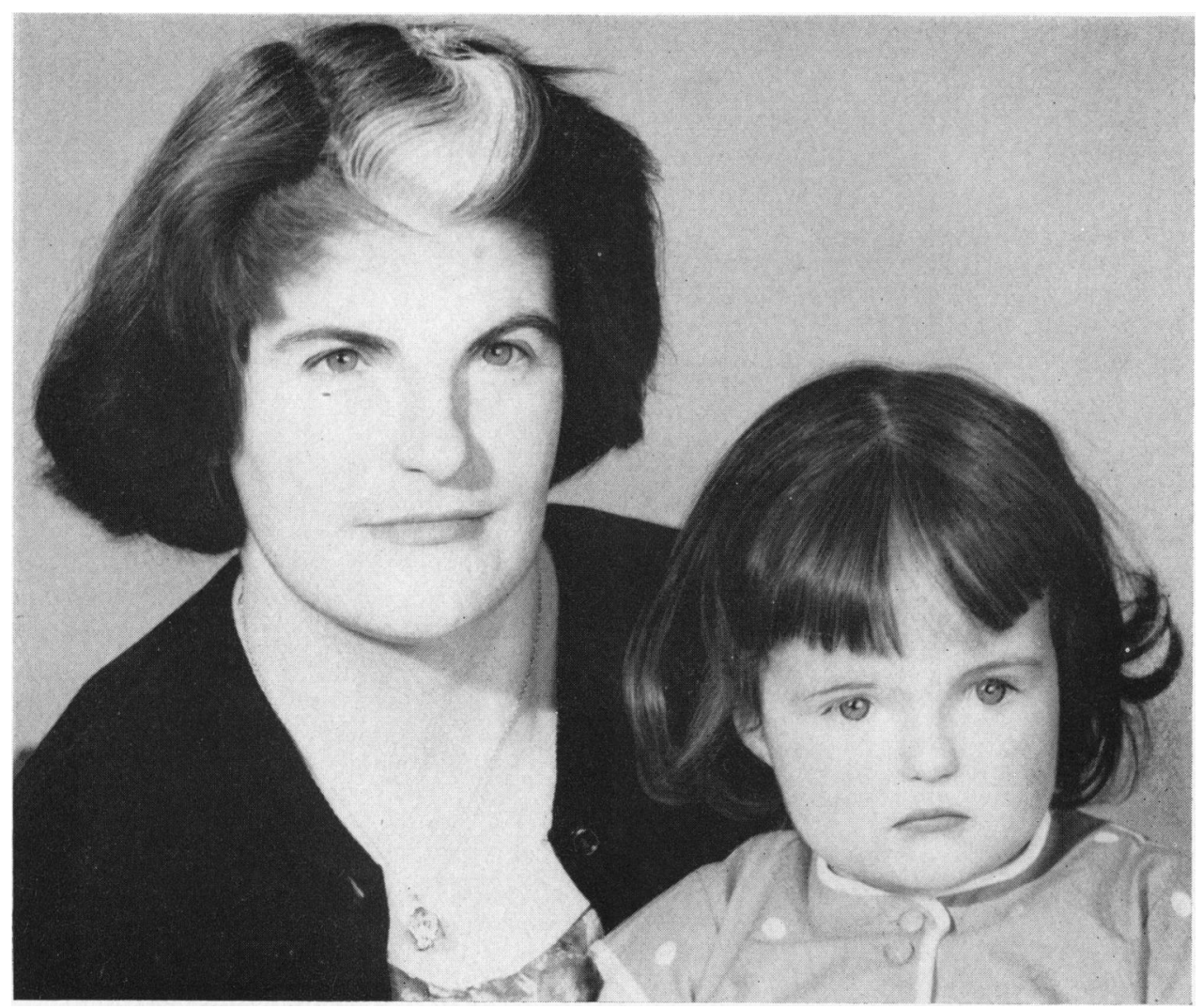

FIG. 2.-Mother and daughter (IV-2 and V-1) showing the white forelock, dystopia cathorum and broad nasal root.

There is little to note about the other members of the family. II-1 had numerous white spots on the skin of his arms for many years which was thought to be vitiligo. III-3 died at the age of 7 years from diphtheria. III-5 at the age of 60 has grey hair. IV-1 has brown isochromic eyes and no sign of dystopia canthorum (inner canthal distance $30 \mathrm{~mm}$., interpupillary distance $60 \mathrm{~mm}$., outer canthal distance $110 \mathrm{~mm}$.). V-2, the sister of the propositus, at the age of $\mathbf{1 0}$ days seemed a normal healthy baby. There is no white forelock, dystopia or confluent eyebrows and she reacts to sounds.

\section{Discussion}

This family history illustrates many aspects of Waardenburg's syndrome. The mode of inheritance is consistent with an autosomal dominant gene of variable penetrance. The most important feature of the syndrome, congenital deafness, may be unilateral or bilateral and this is shown in mother and daughter (IV-2 and V-1). These subjects also show dystopia canthorum. Dystopia was present in two of their forebears (II-4 and 6), and, though the evidence is not very good, probably in two others as well (I-2 and III-6). This anomaly is far easier to see in the living person than in photographs. It is frequently mistaken for hypertelorism (and was so mistaken at the first interview in the present case). Waardenburg gives as the extreme normal adult limits for the inner canthal distance 24 to $39 \mathrm{~mm}$., and 54 to $75 \mathrm{~mm}$. for the interpupillary distance; in women the distances are shorter than in men. In dystopia canthorum the inner canthal distance is $40 \mathrm{~mm}$. or more and the interpupillary distance is normal whereas in hypertelorism both measurements are increased.

As Waardenburg points out his figures for the incidence of the other components of the syndrome are almost certainly under-estimates. Heterochromia iridum is conspicuous if complete (II-4) but easy to miss if only partial (V-1). Confluent eyebrows are not readily remembered and may be disguised (IV-2). The white forelock may be inconspicuous, forgotten in later life or deliberately concealed as it was by one of the present family (III-6) both in herself and in her daughter. (The 
mother shown in Fig. 2 has been accused on more than one occasion of bleaching her own and her daughter's hair.) Premature greying of the whole head of hair occurred in one individual who had previously had a white forelock (III-6) which supports Waardenburg's contention that this is probably another expression of the syndrome equivalent to the white forelock. Wildervanck (1957) reports that in one of his cases two of the forebears had white patches at the back of the head. It is also possible that albino spots of skin ( $\mathrm{V}-1)$ or body hair (IV-2) may be associated with the syndrome.

In other recorded cases there has been no obvious sex-linkage so that there is probably no significance in the fact that all the affected persons in this pedigree are female.

It is of interest to speculate where the gene may have come from in this family. It could have arisen by mutation as seemed to have happened in some of Waardenburg's cases. It could have been brought over here from the Netherlands. There have been two waves of Flemish immigration to this part of England, one in the fourteenth and one in the sixteenth century. (One of the unaffected persons (III-5) has the name of Williment and is of remote Dutch descent.) Yet again the syndrome may be as common in other peoples as in the Dutch but it has not yet been sufficiently recognized and reported.

\section{Summary}

An English family with Waardenburg's syndrome is described. Five members showed various parts of the syndrome and in the sixth it was complete.

I would like to thank Dr. J. F. P. Quinton for permission to publish this case and Dr. A. S. Robertson for referring the family to me. I would also like to thank Dr. A. E. Bashford for Fig. 1.

\section{REFERENCES}

Keizer. D. F. R (1952). Ned. T. Geneesk., 96, 2541.

Klenka, L. (1956). Čsl. Ofthal., 12, 270. Cited in Excerpta med. (Amst.), (1957). Section 12 (Ophthalmology), 11, 54.

Mackenzie, J. (1958). Arch. Dis. Childh., 33, 477.

Waardenbuig, P. J. (1951). Amer. J. hum. Genet., 3, 195.

Wildervanck, L. S. (1957). Ned. T. Geneesk., 101, 1120.

\section{Addendum}

Since this paper was accepted for publication it has been brought to the author's notice that an exhibit of this syndrome was shown by the Royal National Throat and Ear Hospital, London, to the Annual Conference of the British Medical Association in 1958. This included an account of some histological findings indicating complete absence of the organ of Corti and the vestibular membrane. (Brit. med. J. (1958) 2, 322.) 